\title{
Institutional Structure, Participation, and Devolution in Water Institutions of Eastern India
}

\author{
Vasant P. Gandhi ${ }^{1, *}$, Nicky Johnson ${ }^{1} \oplus$, Kangkanika Neog ${ }^{2}$ and Dinesh Jain ${ }^{3}$ \\ 1 Indian Institute of Management, Ahmedabad 380015, India; nickyj@iima.ac.in \\ 2 Council on Energy, Environment and Water, New Delhi 110016, India; kangkanika.neog@ceew.in \\ 3 Entrepreneurship Development Institute of India, Ahmedabad 382428, India; dineshjain@iima.ac.in \\ * Correspondence: gandhi@iima.ac.in
}

Received: 27 November 2019; Accepted: 6 February 2020; Published: 11 February 2020

\begin{abstract}
The paper examines the nature and development of the participatory water institutions in the eastern Indo-Gangetic plains of India, focusing on the aspects of structure, participation, and devolution. Though the physical development of irrigation has made considerable progress in India, the proper management and distribution of water has poised many difficulties. The consequences of this are poor efficiency in water use, inequity in distribution, disputes, high cost, and substantial under-utilization of the potential created. On the other hand, institutional initiatives that aim to improve water management and distribution are seen in some areas/locations, and show a process of arriving at better institutional arrangements. Water institutions are crucial for eastern India and though there are a few examples of spontaneous bottom-up initiatives, much of this development is driven by external interventions including laws, policies, and government programs. Even though under the government interventions, the guidelines and policies are usually uniform and top-down, the local uptake and adoption show substantial variation and divergence and this deserves study. The research is based on review of the literature as well as on six in-depth case studies, and also responses of 510 households involved with 51 participatory water institutions in the setting of the eastern Indo-Gangetic plains states of Assam and Bihar. The paper first takes a brief look at the literature on the foundations and experiences of participatory irrigation management (PIM), and then examines through the case studies and data, the development and variation in the PIM water institution in the given setting. It examines features such as laws, membership, structure, inclusion, participation/involvement and devolution. It finds that inclusion of various groups of people in the institutions is quite good except for women and youth. However, actual involvement of different people varies substantially. The issue of devolution/decentralization versus centralization in decision-making is very important to PIM, and varies across the structure and functions. The association of involvement and devolution to performance indicates that the active involvement of some functionaries and groups is very important, and that devolution in several decisions can considerably enhance performance. The observations provide many useful insights for policy and institutional design which can help improve water resource management in the eastern Indo-Gangetic plains.
\end{abstract}

Keywords: water; irrigation management institutions; participation; devolution; India

\section{Introduction}

This paper examines the evolution and characteristics of the water institutions in eastern India, focusing on the aspects of structure, participation, and devolution. Given the high priority for improving water resource management in eastern India, the need for better institutions, especially for participatory irrigation management, has assumed great importance. Towards this, water user 
associations (WUAs) have been formed in substantial numbers with the objective of sharing or taking over the operation and management of irrigation systems. In some cases, the institutions have evolved from grass-root initiatives, but most of the development in eastern India is driven by national government policies and programs under which the guidelines and policies are usually top-down and uniform. However, since water is a state subject, there are differences in laws and policies across states, and besides, with varying local uptake, the adoption shows substantial variation, resulting in considerable institutional heterogeneity. This can be studied to identify implications for performance. In light of this, the research examines the variation in institutional development, focusing on the aspects of structure, participation and devolution, and their possible links to performance. The research was supported by the Australian Centre for International Agricultural Research (ACIAR) with the objective of understanding and seeking to enhance the performance of PIM institutions in eastern India. The sampled states were Assam and Bihar in the eastern Indo-Gangetic plains. The research started with a set of six case studies, followed by primary data collection from a sample of 510 farmer beneficiaries of existing water institutions. The important issue of devolution versus centralization in decision-making was also examined, including its association with performance. The findings can help the government in formulating better guidelines and policies for PIM and PIM institutions towards improving water resource management. The next section takes a brief international look at the foundations of participatory irrigation management (PIM).

\section{Background of Participatory Irrigation Management (PIM)}

During the last 3-4 decades, participatory irrigation management (PIM) has been adopted and implemented in over 60 countries with various water user association (WUA) models [1]. PIM represents a shift from government managed irrigation systems, which performed poorly, to farmer or jointly managed irrigation systems. It called for inclusion and involvement of farmers in the irrigation management structures, and devolution of powers to them. The mechanism in which the PIM functions, continues to be debated and analyzed [2-4]. It is often believed that PIM contributes to better water management, reduced government operations cost, greater sustainability and better accountability [5-7]. The WUAs are expected to have inclusive user participation, full cost recovery, operation and maintenance (O\&M), and reliable service provision [8]. The experience varies depending on factors such as the institutional and legal framework, financial resources, technical resources and support services, and local leadership. Access to support services, political will, incentives, capacity building, training, cultural factors, farmer heterogeneity, caste-class dynamics, physical system efficiency also matter [1,9]. Phadke [10] finds that in participatory development, enduring and resilient institutions are best built from ground up and they represent flexible engineering that withstand social and political shocks. Coward [11] finds that property rights legitimized by the state (rather than by local customs) do better in creating social coherence and glue for sustainable operation of irrigation works. Meinzen-Dick, Raju and Gulati [12] find that structural conditions can partially explain the nature of the organization and the degree of collective action. Meinzen-Dick [13] finds that the presence of PIM organizations increases the likelihood that farmers would undertake collective maintenance but if this spans more than one village, then the farmers were less likely to undertake collective repairs of the canals.

The primary aims behind devolution of irrigation management include greater user participation, increased collective action, better, and sustainable and equitable outcomes. Based on the guidelines proposed by Vermillion and Sagardoy [14], WUAs are identified as formalized, not-for-profit and user-based organizations with elected representatives from among farmers who are primary users of irrigation water. More than government bureaucracies, farmers are directly interested in improving irrigation management, better efficiency and lower cost [15]. Senanayake [16] finds considerable variation in this internationally. Lam [17] finds that participatory irrigation systems perform better than government-run systems in Nepal, mainly because of greater trust, active involvement in formulating and implementing rules, and greater compliance. Araral [18] on Philippines reports that decentralized 
irrigation systems are likely to better at tackling problems such as dispute resolution, free-riding, and compliance to rules. Gandhi and Namboodiri [7] find that user participation in WUAs in the states of Andhra Pradesh, Maharashtra and Gujarat is active to very active. However, participation may not necessarily be equal as incentives for different stakeholders may be different [19]. Lack of devolution of powers to WUAs from central or state agencies can disincentivize user participation [20]. On financial sustainability, Garces-Restrepo et al. [21] find that in 75 per cent of cases studied, there is increased rate of fee collection. Aarnoudse et al. [8], finds that increased user participation was found to be critical for improved fee collection and on user participation, inclusion of farmers in decision-making at various levels including design and investment decisions is very important.

Capacity building to develop internal capacities with regard to technical, financial and managerial skills considered necessary to manage a WUA and take over O\&M tasks is also recommended. Abu-Zeid and Assioutti [22] indicate that capacity building is a must for WUAs also to adapt to the changing circumstances by increasing the flexibility of institutions and the society. Shah [2] finds that capacity building through investing time and resources by an NGO resulted in considerable success of WUAs. Zhou [19] finds that integrating local contexts in rules, regulations and expectation is crucial for participatory irrigation management (PIM). In this perspective, even though there are broad guidelines and an overall thrust towards PIM nationally in India, since water is a state subject, different states have evolved their own laws, regulations and systems for PIM.

\section{Mandated Institutional Framework in Assam and Bihar}

An outline of the mandated institutional/legal framework for PIM in the states of Bihar and Assam is given in the Table 1 below. The PIM Acts of Bihar and Assam are similar as well as different in a number of ways. Both indicate the institutional structure for different functions and the levels of devolution mandated. The Assam Irrigation Water Users Act, 2004 [23] was enacted with a view to safeguard farmers' right over irrigation systems and also to increase collective action for the management of these systems. The Bihar Irrigation, Flood Management and Drainage Rules, 2003 [24] was framed under the Bihar Irrigation Act 1997, and includes components beyond PIM. Thus, Assam Act focuses on PIM alone whereas the Bihar Act goes beyond PIM in irrigation management.

Table 1. Comparative Picture of the Acts on participatory irrigation management (PIM) in Bihar and Assam.

\begin{tabular}{|c|c|c|}
\hline PIM Act/Rules & Bihar (Government of Bihar, 2003) & Assam (Government of Assam, 2004) \\
\hline Functions & $\begin{array}{l}\text { Operations and Maintenance }(\mathrm{O} \& \mathrm{M}) \text {, } \\
\text { assessment and collection of water rent }\end{array}$ & $\begin{array}{l}\text { O\&M, assessment and collection of water } \\
\text { rent; specific powers detailed at various } \\
\text { administrative levels (outlined in the Act) }\end{array}$ \\
\hline
\end{tabular}


Table 1. Cont.

\begin{tabular}{cll}
\hline PIM Act/Rules & Bihar (Government of Bihar, 2003) & \multicolumn{1}{c}{ Assam (Government of Assam, 2004) } \\
\hline & & $\begin{array}{l}\text { One or more WUAs form Distributary area. } \\
\text { Managed by a Distributary Committee }\end{array}$ \\
& $\begin{array}{l}\text { WUAs from each village in the } \\
\text { command area form Village Level }\end{array}$ & $\begin{array}{l}\text { WUAs and officials of Irrigation and } \\
\text { Committees (VLCs). }\end{array}$ \\
& & $\begin{array}{l}\text { Agriculture Department, max } 5 \text { members } \\
\text { from the General Body as President and } \\
\text { members of Managing Committee. }\end{array}$ \\
\hline
\end{tabular}

Project area-All DCs under a particular project area constitutes Project Committee (PC).

(3rd tier)

WUAs from the whole command area of the canal system form the System Level Committee (SLCs).
General Body of PC constitutes presidents of

DCs. Executive Engineer from Irrigation and District Agricultural Officer from Agriculture Department, max 5 members from the General Body as Chairperson and members of Managing Committee

Apex Committee-Minister, Irrigation Dept, 5 elected people from among Chairpersons of Project Committees 3 from Secretary or Chief Engineer from Irrigation and Agriculture Department Gram Panchayat (GP) President

$\mathrm{PC}$ is responsible for the approval of operational plans based on entitlement area, cropping pattern, soil, as prepared by the competent authority (competent authority is appointed by the Government from the Irrigation Department, any other Government Department or Government-Aided Department)

DC prepares operational plans consistent with the PC plan

WUA prepares and implement a Warabandi ${ }^{2}$ schedule for every irrigation season according to operational plans by DC, or PC; and approved by the same committee

In general Farmers' Organizations (all tiers of governance) are given the power to levy and collect taxes. However, WUAs (at the ground level) are responsible for maintenance of detailed record of water users, land holdings, irrigation system inventory, accounts etc. The $\mathrm{DC}$ and the $\mathrm{PC}$ also are responsible for maintenance of accounts. from farmers from farmers
Assessment of water revenue
SLC maintains detailed register of plot-level watering. SLC assesses the revenue. Farmers can verify with a member of VLC.
Farmers are to make payment to SLC within stipulated time. SLCs then deposit a portion of the revenue to the Government treasury, Divisional CO to be intimated.
WUAs assist the revenue department to collect water rates.
PC is responsible for the approval of plans for maintenance as prepared by the competent authority (appointed by the Government from the Irrigation Department, any other Government Department or area

DC prepares and executes plans for maintenance of distributary and medium drains

WUA prepares and executes a maintenance plan for distributary, minor and field drains 
Table 1. Cont.

\begin{tabular}{lll}
\hline \multicolumn{1}{c}{ PIM Act/Rules } & Bihar (Government of Bihar, 2003) & \multicolumn{1}{c}{ Assam (Government of Assam, 2004) } \\
\hline $\begin{array}{l}\text { O\&M finance for Farmers' } \\
\text { Organization }\end{array}$ & $\begin{array}{l}\text { SLC retains a portion of the revenue } \\
\text { collected, the proportion of which is } \\
\text { decided in the MoU. }\end{array}$ & $\begin{array}{l}\text { Grant from the government as a part of water } \\
\text { tax collected in the area of operations of the } \\
\text { Farmers' Organization; other government } \\
\text { grants, grants/donation/loans from financing } \\
\text { agencies; income from property and assets } \\
\text { attached to the irrigation system, fees } \\
\text { collected. }\end{array}$ \\
\hline $\begin{array}{l}\text { On non-payment of water } \\
\text { revenue by SLC to WRD }\end{array}$ & $\begin{array}{l}\text { Water of supply could be stopped in the } \\
\text { next season. }\end{array}$ & Not mentioned \\
\hline Changes to this Act/Rule & $\begin{array}{l}\text { State Government Legislature (for Act), } \\
\text { Water Resources Department (for Rules) }\end{array}$ & State Government Legislature \\
\hline
\end{tabular}

Source: Government of Assam (2004) and Government of Bihar (2003). Note: ${ }^{1}$ : paperwork, ${ }^{2}$ : rotational water allocation system.

In both the Acts, bottom-up institutional structures are recognized, with Water User Association (WUA) (an association of individual water users) being the primary body. While in Assam, WUAs are directly notified as an association, in Bihar registered WUA could voluntarily approach the government seeking a lease through a Memorandum of Understanding (MoU). The PIM Act of Assam is more detailed with regard to various components such as members, structure of farmer organizations and resources. The PIM rules in Bihar are somewhat less detailed and at times vague. The administration in both the states is primarily top-down (controlled, directed, or instituted from the top level of the administration), but with some difference.

On membership, the Assam Act states that WUAs in Assam must have five ex-officio government officials from the Irrigation and Agriculture Department. All other committees also require representation from the government. This indicates a more-centralized nature of PIM in Assam. In Bihar, in contrast, no government representation is required at the association or committee level. However, WUAs are required to closely work with the government department. Thus, Assam has a more centralized approach consistent with a larger role played there by the central government.

Top-down nature is also seen for operational works. In Assam, operational plans for water demand assessment and distribution are recommended by the government directly through an appointed authority. The Project Committee and Distributary Committee makes their plans on the basis of these operational plans. In Bihar, while the System/Central Level Committees (SLCs/CLCs) develop water demand plans based on data collected by the Village Level Committees, the authorization of the plans, is subject to the scrutiny by the Canal Office of the Water Resources Department, particularly where the supply/availability of water is constrained.

In finance for operation and maintenance, state governments in both the states have considerable power indicating limited devolution in these functions. In Bihar, SLCs/CLCs, and not WUAs/VLCs are allowed to retain a portion of the fee collected as decided in the MoU. In case of Assam, the farmers' organization/WUA receive grants from the government but cannot retain any share in the fees collected.

In some functions, however there is bottom-up engagement, for instance in maintenance works in both the states. In Assam, maintenance plans are prepared at all tier levels for their respective operational areas. The WUAs, at the ground-level, engages in maintenance works of the distributary, minors and field drains. The Distributary Committee looks after works in the distributary and medium drains, and the Project Committee approves the overall maintenance plans. The allocation of maintenance responsibilities is not prescribed, but is mutually agreed up during the development of MoU. For fee assessment and collection, WUAs in Assam are required carry out all the ground work. In Bihar, farmers are required to deposit their fee by verifying the assessment through VLCs. In both states, PIM Act/Rules do not cover equity or inclusion based on gender and caste. 


\section{Participatory Irrigation Management (PIM) in Assam}

Assam is highly dependent on agriculture, and 85 percent of its population depends directly or indirectly on agriculture for their livelihoods. The state receives a substantial amount of rain (annual average $2818 \mathrm{~mm}$ ) and has large river flows, but to increase agricultural production and incomes further, irrigation is needed for reliable water availability and for supporting additional crop seasons after monsoon. Towards this, a number of important irrigation schemes have been initiated in Assam. The state has mainly two kinds of irrigation schemes: Flow irrigation and Lift irrigation. Including major, medium and minor schemes, the total irrigation potential created is estimated to be about 881,000 hectares. Poor delivery and utilization of water at the local level and unsatisfactory irrigation management, has led to a large and growing gap between potential created and potential utilized or actual irrigated area (in 2018 the irrigation potential created was 996 thousand hectares whereas the potential utilized was 239 thousand hectares (24 percent)).

For better irrigation management, and to improve irrigation efficiency, active participation of farmers is considered to be useful and important, and this is sought to be achieved through Participatory Irrigation Management (PIM) with the formation of Water User's Associations (WUAs). The WUAs are made responsible for the distribution of the water and the operation and maintenance works in the schemes. The WUAs are generally formed within the command areas of irrigation schemes (major, medium or minor) and help bring about farmer participation in the management of irrigation systems. They are expected to achieve efficient and equitable distribution of water higher agricultural production and incomes.

WUAs are formed in accordance with the provisions of Section 3 (1) of the Assam Irrigation Water Users' Act, 2004. The Associations are registered under the Societies Registration Act, 1860. This is done with the objective of transferring the operation, maintenance and management of irrigation schemes or part thereof to WUA in accordance with Rule 38 (2) of the Assam Irrigation Rules, 1997.

The main objectives of the government for Participatory Irrigation Management (PIM) and the formation of Water Users' Associations are stated as [25-28]:

1. To create sense of ownership among the users for the water resources and the irrigation systems, and promote preservation and economy in water use;

2. To enhance service delivery through improved operation and maintenance;

3. To achieve efficient utilization of water resources through supply as per crop needs;

4. To achieve equitable in water distribution;

5. To increase production per unit of water and increase production per unit of land;

6. To encourage collective responsibility for collecting water charges and payment to government;

7. To create a conducive environment between the Irrigation Department and the water users;

Even though a good number of Water Users' Associations have been formed within the command areas of irrigation schemes, the objectives of the formation of the WUAs have not been achieved as expected. There is still a vast gap between Irrigation Potential Created (IPC) and Irrigation Potential Utilized (IPU). A huge area of created potential is lying unutilized. The farmers are often not willing to go for multiple cropping, as they are accustomed to single cropping only, leading to non-utilization of assured irrigation. Further, imposition of irrigation service charges is also one of the reasons for non-participation and non-utilization of created potential by the farmers. The farmers prefer and are used to getting "free water" from government irrigation schemes and sometimes even do not take the irrigation facilities for the fear of payment demands for irrigation service charges, and prefer to depend on rains for their crops. This may also be partly due to low awareness or motivation of the farmers for higher production and incomes through irrigated agriculture. It was expected by the government that the development and proper functioning of WUA will overcome this situation and help reduce the gap between Irrigation Potential Created (IPC) and Irrigation Potential Utilized (IPU).

Further, sufficient funds are required for operation and maintenance in functioning irrigation schemes for effective delivery of irrigation water to the farmers. Since the State's Annual Budget are 
often did not have sufficient funds to meet the expenditure for operation and maintenance, the system of realization of Irrigation Service Charges from beneficiary cultivators was introduced in Assam in the year 1993. This was done in accordance with the provision under Section 41 of the Assam Irrigation Act, 1983. But the position regarding the collection of Irrigation Service Charges is not satisfactory, and in spite of endeavor of the departmental officials, the position of collection has not improved.

Formation of WUAs, though, has made progress and 1407 Water Users Associations have been formed in the command areas of Irrigation Schemes. Out of these, 794 WUAs are registered under the Registration of Societies Act, 1860 with the Director, Registration of Societies and it is believed that these WUAs are active. The Irrigation Department is endeavoring to form more WUAs within the command areas of irrigation schemes and contemplating handing over of the schemes to the respective WUA for operation and maintenance (including minor repair). For this, the Department has proposed an amendment of the Assam Water Users' Act, 2004 which would empower Water Users' Associations to collect Irrigation Service Charges and utilize the entire amount for operation and maintenance in their respective jurisdictions.

\section{Participatory Irrigation Management (PIM) in Bihar}

Bihar's economy is also substantially agricultural and the population depends extensively on agriculture for livelihoods. The population density is very high at about 1200 per sq km which is 4 times the national average of about 300 per sq $\mathrm{km}$. Most of the farms are very small, with an average holding close to only 1 ha. Raising agricultural productivity and incomes is of great importance, and significant investments have been made in irrigation which has increased the irrigated area to 2.48 million ha by 2001, and helped Bihar to become self-sufficient in food. However, the irrigation potential created is 5.35 million ha which indicates a huge gap ( 2.87 million hectares based on figures above) to be bridged by better irrigation management and improving water use efficiency, particularly through farmer involvement and participatory irrigation management [26].

The major problems faced, summarized by Jayshankar [26] include:

- Deteriorating the canal system due to poor maintenance;

- Under-utilized irrigation potential;

- Inequality in water distribution;

- Low quality of services to users;

- Need to enhance irrigation rates and improve their collection.

Earlier, the government irrigation management set up had little or no participation of farmers users, and was not accountable to them. The different departments or agencies involved such as Command Area Development Authority, and the Agriculture, and Extension departments had no coordination, and there was little attention to the efficient and economic use of water. It was realized that the farmers had the highest stake in the irrigation system performance, and it was therefore very important to have their participation and involvement in the management of systems. Given this, reforms in the systems and institutions managing irrigation were urgently required, and even transfer to the users to a certain level.

The main objectives of this approach of Participatory Irrigation Management (PIM) [25-28] were stated as:

1. To start farmer participation in water management, scheduling, distribution and maintenance;

2. To improve water use efficiency;

3. To make best use of rain, canal and ground water in conjunction for increasing irrigation and cropping intensity;

4. To develop consideration for economy in water use among the users;

5. To guide crop choice and management for maximizing water use efficiency and incomes;

6. To define responsibility for water distribution and maintenance between users and the department; 
7. To promote equity in allocation and supply of water amongst the users;

8. To facilitate dispute resolution among farmers;

9. To entrust group responsibility on the farmers to collect water charges and make payments to government;

10. To improve water delivery by the department as per crop needs to improve efficiency and reduce losses;

11. To create a conducive and healthy atmosphere between the department and water users.

Following the National Water Policy of 1987 [29], the Government of Bihar announced its Irrigation Policy of 1993. The policy indicated that participatory irrigation management (PIM) would be promoted through the setting up of farmers' water user associations (WUAs) which can later take over the management of irrigation systems, and the water charges collected would be partly shared with them [30]. Following this, the Government of Bihar passed 'The Bihar Irrigation Act, 1997, which provided a legal status to Water Users Associations, and indicated that the Government may transfer any distributary, minor or channels to the WUAs for maintenance and operation if considered appropriate. The WUAs would be provided authorized supply of water at the head regulator. This would be in proportion to the area irrigated, and if there is a deficit, that would be shared equally [31].

The Paliganj Distributary experiment on farmers' participation of the 90's in Bihar was quite successful (discussed below). Based on this the Water Resources Department of Bihar prepared guidelines for implementing PIM which have been referred to as the Bihar Model of PIM [26]. Based on this, many distributaries have been handed over by the Water Resource Department to the WUAs. The target is to handover about $50 \%$ of the total the culturable command area (CCA) of major and medium irrigation project of the state to PIM. The state's Water and Land Management Institute (WALMI) organizes training programs at Patna and in the field to train and motivate farmers and field officers of the department to take up PIM. At the state level there is a Steering Committee for this under the Development Commissioner of the state. There is a PIM cell in the Water Resources department under a superintending engineer for monitoring the implementation of PIM. Crop command area (CCA) of 177,450 ha under 64 more distributaries had been identified to be brought under PIM.

\section{PIM in the Two States and its Institution Structure}

Both the states economies have substantial dependence on agriculture for livelihood and incomes, and in light of this both have invested substantially in developing the irrigation potential. In Bihar, the efforts towards developing irrigation started much earlier even during British rule, where as in Assam the effort is more recent. However, in both states, a substantial gap has developed between potential created and potential utilized. In Bihar this is substantially due to deteriorating canal systems and inequality in water distribution. In Assam this is due to poor utilization of the irrigation water caused by lack of farmer involvement. Thus, the states come to the solution of PIM from somewhat different problems. However, the goals of PIM in the two states are very similar. Whereas in Bihar there was a successful PIM experiment (Paliganj) leading to the formulation of a PIM model which is then sought to be replicated all over the state. In Assam, no such model has yet been identified. In Assam given the stronger top-down orientation, the design does not have sharing of the water fees/charges with the WUA, and only recently this has been proposed. However, in Bihar given the central problem of improving maintenance, the sharing of the fees has been accepted since long. Whereas it is reported that 1407 WUAs have been formed in Assam, 794 registered, the number of WUAs is smaller in Bihar, and is under 25 Central Level Committees.

In terms of the mandated structural design, the water user associations (WUAs) in Assam and Bihar typically have the same organizational structure. There is a central level committee (CLC) which is registered under society act and considered as the apex body. Under CLC, many villages may be included and for each village a separate Village Level Committee (VLC) is created. In some cases, some subcommittees may be established under VLC called Water/Outlet/Field committees. (See Figure 1). 


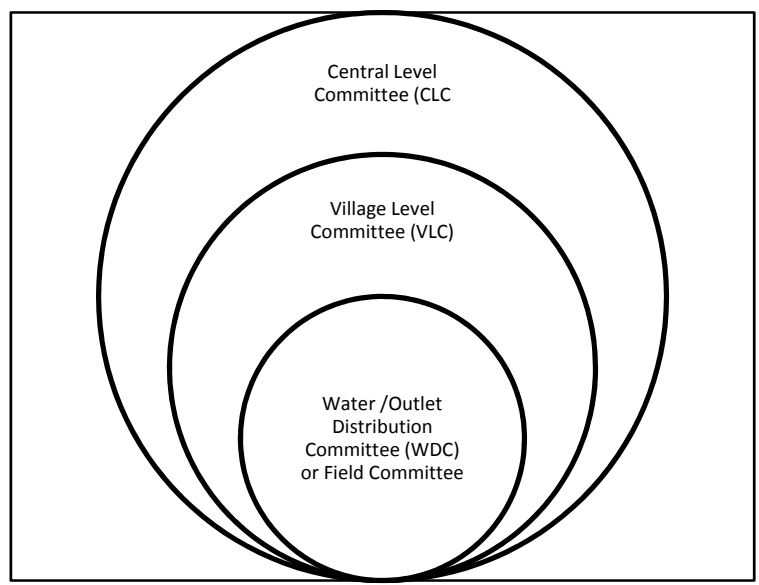

Figure 1. Water user association (WUA) organization levels.

The CLCs have an executive body and general body. Executive body has positions of president, vice-president, secretary, assistant secretary, treasurers and advisors. (See Figure 2). The CLCs are involved in government relations and financial matters including provision of resources to VLCs, and solving any conflicts between VLC's. The VLCs manage the village level water allocation and distribution, collection of fees from farmers, and minor repairs. The VLC generally also has an executive body with president, vice-president, secretary, and assistant secretaries, as well as a general body. The general body members are the farmer water users of the village. The president and some executive members of VLCs form the general body of the CLC, and out of these, the executive body members of the CLC are elected.

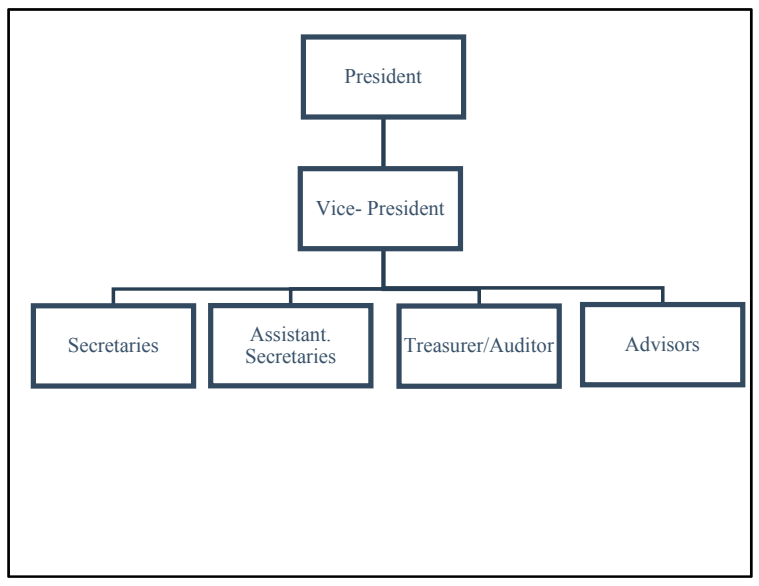

Figure 2. Organization structure.

\section{Case Studies of Water User Associations in Assam and Bihar}

In order to obtain a real picture of PIM in action in the states of Assam and Bihar, detailed case studies were undertaken of a sample of WUAs in the states of Assam and Bihar. Brief write-ups from these are given in the sections below. The write-ups vary due to differences in irrigation systems and the available information. The case studies in Assam were selected to cover a diversity of existing irrigation systems and geographic locations in the state: Maloibari for river lift irrigation, Sukhajani for canal irrigation, and Khairani for river diversion. Geographic diversity was also considered, with Maloibari being south of the Brahmaputra river (which divides the state) and Sukhajani and Khairani north of the Brahamapura. In the case of Bihar, such diversity in systems does not exist-almost all are canal systems. Here the choice was made in terms of upstream and downstream in a canal system, and north (more flood prone) and south of the Ganges river which divides the state. R P Channel 3 is 
upstream in the Sone canal system and Paligunj is downstream in the same system-both south of Ganges. Jetwalia is north of the Ganges and downstream on the Gandak canal system. Thus, the case studies cover a diversity of irrigation systems and locations in eastern India.

\subsection{Water User Associations (WUAs) in Assam}

\subsubsection{Maloibari (WUA)—Kollongpuria Krishak Sanstal Committee}

The Maloibari Lift Irrigation Scheme (MLIS) is located in the Maloibari village, about $60 \mathrm{~km}$ east of Guwahati and south of the Brahmaputra river in Assam state. It is in the Kamrup (Metro) District on the Kollang river which is a tributary of the Brahmaputra. The area around the village is largely flat and frequently affected by floods. The population of the village is about 30,000 in which a large section is engaged in labor. About 50 percent of households are landless daily-wage workers, 30 percent are farmers with secure tenure, and 20 percent are service employees. In social groups, about 80 percent of the households are of scheduled (backward) castes, 5 percent scheduled (backward) tribes, and 15 percent other/higher castes. The education status is quite good with only about 10 percent illiterate, 20 percent with primary education, 50 percent with middle to high school education, and 20 percent with college education. Agriculture is the major source of income, the main crop being rice, and the second crop if taken, is frequently vegetables such as tomato or brinjal. Many are also engaged in fisheries - the village has about 200 fish ponds. There are a number of small local rice mills in the village to which the farmers sell their paddy output, and besides wholesale traders come from outside to purchase paddy and fish from the farmers. The farmers are increasingly shifting from subsistence to market orientation, and this along with a good education status, increased the inclination and capacity of the people towards developing irrigation and PIM.

Thus, even before the government's involvement, the farmers in the Maloibari area had taken the initiative on their own and formed an informal water user association in 1969-1970, and installed 3 pump centers for lift irrigation from the river. The activity was successful and grew further through government support under the Maloibari Lift Irrigation Scheme (MLIS) scheme which was implemented first during 1972-1973 to 1975-1976. By 1992, 27 pump centers had been established along with 27 corresponding WUAs in the form of Village Level Committees (VLCs), and a Central Level Committee (CLC) was organized above them called the Kollongpuria Krishak Sastal Committee. By 2007, all the VLCs and the CLC were registered. Further improvements were taken-up during 2008 to 2010. Because the water level in the Kollang river varies substantially and the banks are eroding, the pumps are installed on floating platforms on the river close to the bank. Each pump centre has 2 pump-sets of 20 hp capacity. The scheme covers 9 villages, and the distance between pump centers is typically less than $1 \mathrm{~km}$ along the river, and distance between the first pump and the last pump centre is about $8 \mathrm{~km}$. The pump centers are operated by government staff which include power pump operators, assistant operators, electricians, mechanics, helpers and watchmen (total 54). They work in coordination with the CLC and VLCs, and if a critical government staff is absent, a VLC member takes over. Currently, the kharif (monsoon crop) potential is 1246 hectares and the rabi (winter crop) potential is 745 hectares, and the total potential comes to 1991 hectares.

The VLCs has an Executive Committee with a President and Vice-President, and also a Secretary, Assistant Secretaries and a Treasurer. Each VLC also has a Water Distribution Committee (WDC) or Field Committee which has some representatives from the Executive Committee and ordinary local members. The WDC manages the water distribution under the VLC. The Central Level Committee (CLC) consists of representative executive members from each VLC. The CLC has an elected executive committee with a President and Vice-President, as well as 1 or 2 Secretaries, Assistant Secretaries, and a Treasurer. The CLC manages the overall matters of maintenance and repairs which are raised by the VLCs. For major repairs, the CLC raises the issues with the government and pursues implementation. CLC also undertakes the collection of water charges from members, and deposits the money with the government. 
The pumps are operated and irrigation water provided generally from November to April (after the monsoon season: May-Oct in northeast India). The WDC prepares and implements the schedule of water distribution. Water is generally released individually to the farmers from the channel/canal based on a time-frame given. Generally, a farmer gets about five hours of irrigation water on the day of the schedule. WDC members may also personally visit the fields to determine the water requirement and accordingly vary the supply. If a farmer requires and requests more water than allocated, the VLC decides about the supply. All the members monitor the distribution together.

Water charges are generally collected twice a year: in May (end of the irrigation season) and in Oct-Nov (beginning of the next season-for arrears). The rates are fixed by the government. The water charges are a flat Rs. 750 per year as irrigation service charges for paddy, plus Rs. 10/bigha of cropped area per year as water charges ( 1 hectare $=7.47$ Bigha), and Rs 5/bigha per year for welfare fund. If CLC is asked by the government to collect these charges, then the CLC often engages collection agents, and pays a commission of $10 \%$ to the agents. VLC provides a receipt for the amounts collected. All the money collected has to be deposited in the bank account of the Assistant Executive Engineer (Sonapur). Generally, the extent of recovery of water charges is rather low at less than $40 \%$. Repair, travel and miscellaneous expenses can be drawn from the funds collected. The CLC and VLC executive members are honorary and not paid.

The WUA has played a very important role in the success of the Maloibari Lift Irrigation Scheme (MLIS). CLC and VLCs have greatly helped coordinate the pump operation, water distribution, repairs and maintenance, and the necessary communication with government. If any disputes arise, a meeting of the VLC is first called. If the matter cannot be solved, it is taken to the CLC level. These meetings provide a very important mechanism for better functioning, solving problems and coordination, and show the decentralization and devolution of decision-making envisaged in PIM in action. Small repair and maintenance works are also carried out by the VLC and CLC in coordination. If more funds are required, the CLC calls a meeting of all the VLC members, though not frequently-the last one was in 2015. In the recent years, greater variability in the rainfall and the flood situation has been observed, and this has increased the need for water management and PIM. The improvement in marketing linkages and infrastructure with economic development is also leading to greater demand for water to add a cropping season and increase yields, thereby enhancing the need for PIM.

\subsubsection{Sukhajani (WUA)—Eastern and Western Canal Water User Associations}

The Sukhajani Flow Irrigation Scheme (Sukhajani FIS) is in the Darrang district in northern Assam. The scheme is based on the river Sukhajani which originates from Bhutan and ends in the Brahmaputra. The scheme is centered around the Batabari village which is about $110 \mathrm{~km}$ from Guwahati north of the Brahmaputra river. Batabari is a medium sized village with 317 households and a population of 1788 as per Population Census of 2011. It has a literacy rate of 62.1 percent. Scheduled tribes constitute 12.9 percent of the population, and scheduled castes 0.22 percent. The rest 86.86 percent belong to other castes and tribes. Of the working population in the village 39 percent are identified as farmer-owners and 28 percent as agricultural laborers. The rest have other sources of employment. The land is mainly flat and agriculture is the major source of income. The main crop is summer paddy (rice) and maize. Pulses are grown on about 5-10 percent of the land and include lentils, pigeon pea and black gram. Vegetables are grown throughout the year but mainly in the winter season, and include cabbage, potato, tomato, french beans and other vegetables. There are also small tea gardens producing tea. The produce is mainly sold in the Kharapetiya about $7 \mathrm{~km}$ away, which has a large vegetable market from where about 20 trucks usually leave daily for Delhi and other destinations. There is also a cold storage at Lalpoli at about $7 \mathrm{~km}$. These have made vegetable growing a major income generating activity in the scheme area. Given the good market connection and literacy, the community shows good potential for PIM.

The Sukhajani FIS has been constructed in phases and the first phase was during 1955-1956 to 1958-1959. The Command Area Development (CAD) work to enhance benefits was during 1974-1975 
to 1978-1979. Second phase of the project was undertaken from 1984-1985 to 1987-1988, augmentation during 1993-1994 to 2007-2008, and remodeling during 2008-2009 to 2009-2010. Three types of canal were built: main canal, branch canal, and distributary canal. The irrigation potential created under the scheme is 1450 hectares net irrigated area. With a kharif (monsoon crop) potential of 1450 hectares and a rabi (winter crop) potential of 400 hectares, and gross potential is 1850 hectares. The scheme benefits 14 villages. 550 families are benefitted. The PIM initiative and the formation of the WUAs took place only in 2008, when two WUA Central Level Committees (CLCs) were created, East WUA and West WUA. Villages which are east of main Sukhajani FIS canal come under the East WUA, and those to the west come under the West WUA. The executive committee members were changed in 2009-2010 and the WUAs were registered through the Irrigation Department in 2011. Village level committees (VLCs) have been formed under each CLC.

The East CLC executive committee has 7 members and the West CLC executive has 6 members. Each CLC has a President and a Secretary, but no WUA executive member is in the local Gram Panchayat (village governance institution). No formal elections have been held yet and no formal rules have been made. The Government has announced the guidelines, but many are not being followed. The WUAs have started communicating their problem to the government, and seeking solutions. The WUAs have meetings with the government officials 2-3 times in a year and during this the Sub Divisional Officer and the Superintending Officer of the irrigation department are present, and the meetings usually last for about 1-2 h. The WUAs try to make sure that the water reaches throughout the command area, but the canals are old and damaged and earlier the contractor appointed by the government was not repairing the canal. However, after the WUAs repeatedly raised the issue with the government, the problem has been solved. This shows a change from a top-down to a bottom-up approach for solving problems as desirable in PIM. Water is generally available for five months in a year, mainly during June to October (summer/rainy season). Usually no specific schedule is decided by the WUA for the release of the water, but if there are conflicts between members, the WUA intervenes and tries to solve the problems. No water is available in the winter season when it would be very useful for an additional crop of vegetables for which there is growing urban demand. However, there has been no effective response towards this even after PIM and WUA formation.

\subsubsection{Khairani WUA-Jopadong Pagladia No. 2 Group Bund Dong Committee}

The Khairani WUA is based around the Jopadong village which is located about $100 \mathrm{~km}$ north of Guwahati in the Baksa District of Assam on the Bhutan border. The area is often called Bodoland given its substantial Bodo tribe population. The area has a sloping and hilly terrain with fast flowing rivers coming from Bhutan. Japadong village has a population of about 400 and is near the Pagladia river. About 90 percent of households are farmer-owners, and 10 percent are agricultural laborers and service employees. 80 percent of the households belong to several scheduled tribes and the rest 20 percent to other castes and ethnic groups, which includes Nepali, Assamese, Adivasi and Muslims. The literacy rate of Jopadong is 58 percent. Agriculture is the major source of income and most people are engaged in agriculture. The major crop is rice, and the second crop when taken includes mustard, cabbage, potato, chilies, tomato, bitter gourd, and ridge gourd. Fisheries is a common small scale activity, and animal husbandry includes goat, duck and poultry farming. The diversity of people and crops as well as the tough terrain poses serious problems for undertaking irrigation and PIM.

People from many different regions and ethnic groups migrated to the Jopagdong village area before 1958. They included Bodos, other tribes, Nepalis, Muslims and Assamese. The terrain was sloping and difficult, soils were bad, and there was severe water scarcity. As a result, agriculture was very poor. Given this challenging state, a concerned villager, Someshwar Basumatari, called a meeting one day in the early 1960s to discuss the situation and arrive at ideas and solutions. After much discussion, he was able to convince and inspire the people to form an informal group or water user association to try and solve the problems (and later he became its founder President). There was a fast flowing river (Pagladia river) coming out of Bhutan at the nearby Chowki Village, and it was 
determined that if they could build a barrier there, they could divert part of the water towards the village. They could then build a canal to bring the water to the village. The group set up a work camp at the site where everyone could work and stay. The only contribution expected from the members was their labor. The members brought their own tools/instruments and voluntarily worked at the construction site. With great group effort they were able to build a barrier on the river with boulders, wood and grass, which could divert part of the water towards the village. A canal was then built in a similar manner with voluntary labor contribution. It actually took the WUA four to five years to construct properly the required structures and the canal, and the system became fully functional only in 1968-1969. Once the structures were completed, water began to flow to the village farms. Other structures were made to control and manage the water distribution. With irrigation water becoming available, the agriculture in the village was transformed. Earlier, the farmers could grow only subsistence crops such as yam, but with water becoming available, they could grow many valuable crops such as rice, pulses and vegetables. They could also obtain much higher yields and all this transformed the economy of the village. This work and achievements of the villagers were actually not known to the outside world until recently when the irrigation department officials heard about it and made a visit.

The WUA continued to function informally for many years, but during this, when the big seasonal floods came in the river, the loose structures were frequently damaged or destroyed, and the WUA had to be built them again with the same voluntary work. Given this situation, in the early 1990s, the WUA recognized the advantage of making the association official so that they could become eligible to get government technical and financial assistance and build strong and durable structures. The registration of the WUA was done in 1994-1995. After registration, assistance of about Rs. 3 lakhs (lakh =100,000) was initially received from the government to construct technically sound and durable structures, and further Rs. 5 lakhs were made available for more structures. With the assistance and technical inputs from Irrigation Department engineers, the construction of a strong technically sound diversion structure at the headworks with proper gates was taken up and 6 large canals and 26 sub-canals were constructed. This work and activity has expanded into the Khairani Flow Irrigation Scheme.

Under this now a total 14 Central Level Committees (CLCs) have been organized. Each CLC covers a large number of villages and members. The case study focused on one CLC, the Jopadong Pagladia No. 2 Group Bund Dong Committee. There are 14 villages under the Jopadong CLC, and each village has a Village Level Committee (VLC). The President and Secretary of VLCs are members of the general body of the CLC which has about 30 to 40 members. From among these, the CLC constitutes an Executive Committee, which also includes two Advisors who have long standing experience in running the WUA, Horkeshwar Devri and Prabhat Das. The 14 VLCs have a total of 4322 farmer members. The 14 villages are under 7 revenue villages. The CLCs and VLCs Presidents have a tenure of three years.

A very interesting aspect of the Khairani WUA is the way these WUAs work. From the beginning, the WUA had developed a unique system of working rules and compliance methods. No money or charges or tax is ordinarily collected from the members. The principal expectation from the members is that they contribute their labor for the projects and activities undertaken by the WUA. When the call is given by the President or officials of the WUA for a project or activity, every member must report for work. If they do not report, a fine of Rs. 150 per day must be paid. If a member conveys that he is sick, then this is confirmed by an executive committee member, and the person must also make a written application. If the member does not report for more than 3 days, then apart from Rs. 150 per day, an additional fine of Rs. 125 per day is levied. If the member does not attend for $50 \%$ of the work days, then in addition to Rs. 150 and Rs. 125 per day, the member has to pay Rs. 500 . If a member eventually does not pay the fines levied then a sanction called "Kuruk" is implemented. In this, the WUA members descend on the person's house and seize/take away property of a value equal to the total fines from his house. The fines become an important source of income for the WUA. The amount collected is used to meet the costs of projects or repairs when needed. The executive 
committee members are honorary, but usually out of the collection, each is entitled to 1 mun or $20 \mathrm{~kg}$ of rice. Fines may also be levied in other matters. If a member is absent for meetings he has to pay a fine of Rs. 150, and if a member takes more water than allotted, then he also has to pay a fine. If a member is not able to pay the fine then another member is allowed to pay on his behalf.

The water is distributed by the WUA based on the level of water in the canal, which is measured by the depth of the water in inches. Based on this a time duration of the water flow is allocated to each member, and the gates are opened for release based on this time schedule. If plenty of water is available then the time restrictions are relaxed. Executive members of each VLC monitor the water flow and release. The executive committee meets every Wednesday, but a meeting can be called whenever required. The General Body meets at least once a year. Remarkably, no major conflicts have occurred in these WUAs/ villages regarding the water management system or the working of the WUA. Khairani WUA offers an excellent example of a farmer managed system with completely decentralized decision-making. Strong leadership, organized approach, continuing involvement of experienced leaders, and strict methods of enforcing compliance have played a major role in the success of PIM in Khairani.

\subsection{Water User Associations in Bihar}

\subsubsection{Paliganj WUA—Paliganj Viratni Krishak Samiti}

The Paliganj distributary with a command of 12,000 hectares originates from the Patna Canal which is the main canal of the Eastern Sone Canal System built in 1874 in British India. The distributary and its two sub-distributaries serve 76 villages in Patna district. The village Paliganj is located about $50 \mathrm{~km}$ south of Patna in the Patna district of Bihar state south of the Ganges river near the Sone river. The area is largely flat and fertile and has mixed alluvial soils locally called "domath". Paliganj is a large village with a population of about 9000 . The population density of the area and state is very high, the Bihar average being about 1100 per sq $\mathrm{km}$ compared to the national average of about 325 per sq $\mathrm{km}$. Most of the farms in the village are very small ( $<1 \mathrm{ha})$. About 40 percent of the households belong to scheduled (backward) castes, 30 percent to scheduled (backward) tribes, and 30 percent to other castes. In education status, the literacy rate is 65 percent. Agriculture is the major source of employment and income and the major crop is by far rice. The second major crop is wheat. Other crops include lentil, chickpea, rapeseed-mustard, and vegetables such as potato, spinach and brinjal. Soil testing and seed testing laboratories have also been established under the WUA.

In 1989, under the Indo-US Water Resources Management and Training Project supported by the United States Agency for International Development (USAID), the Water and Land Management Institute (WALMI) Patna, Bihar, undertook focused activity to try and improve the irrigation performance of the Paliganj Distributary [22,28,32]. The system had deteriorated substantially. There was anarchy and the head-reach farmers frequently blocked and breached the canal to take away the water. There were severe disputes and tensions arising mainly from water issues and land and caste issues. The WALMI team supported by the USAID team, spent many months having a dialogue with the farmers, discussing new ideas, possibilities, and change. The meetings eventually led to the formation of the Paliganj Distributary Farmers Committee (PDFC) which consisted of representatives from the 20 villages (initially). In these villages, Village Irrigation Committees (VICs) were formed.

More villages and members joined over time, and PFDC was registered as a legal society in 1994 (a Central Level Committee-CLC), with Village Level Committees (VLCs) under it. One person from each VLC executive committee was made a member of the PDFC. The PDFC executive started meeting every fortnight and established communication with the villages regarding distribution of water and agricultural activities. 55 villages were gradually brought under the PDFC-CLC with VLCs formed in 45 of them. The PDFC and each VLC has an executive committee (EC) typically of 11 members from across farm size and caste groups. The VLC ECs have a three-year tenure and EC members can continue for two terms. The EC selection is by consensus or election. A representative from each VLC 
EC is a member of the Paliganj Distributary Farmers Committee (PDFC). Generally the VLC EC meets around the 15th of every month and the PDFC EC meets around the 30th of every month. Studies of the impact of the Paliganj PIM activity found that there was substantial improvement in the condition of the canal, the conveyance capacity, the availability of water including at the tail-end, and in crop yields [22,28,32]. This indicated significant benefits from devolution through PIM. The government has a special cell on PIM and WALMI continues to be involved with regular training programs on PIM for WUA leaders and government officials.

Recovering irrigation and water charges is a big challenge for the VLCs and the CLCs. It is reported that only about $5 \%$ of the farmers pay the charges without any intervention; from about $15 \%$ pay when they are informed, and about $30 \%$ pay after repeated effort. A $10 \%$ commission is given to the collection agents. Yet about $40 \%-50 \%$ of the farmers do not pay. In Bihar, 30 percent of the water charges collected have to be deposited with the government treasury, and balance 70 percent can be retained by the WUA for system upkeep and other irrigation management works. If more money is needed, some farmers voluntarily contribute (often up to Rs. 1000), including through labor contribution "Shramdan". These resources are largely used for repairs and maintenance of canals. The positive role of external experts/agencies in initiating change towards PIM is brought out very well in this case-the role played by the WALMI and USAID project teams. Apart from farmer leadership, positive government involvement and support is also very important and this needs continuity to overcome new hurdles and sustain the benefits and improvements. The system of sharing of the water charges collected with the WUA (at 70 percent) for system upkeep and maintenance is also an important enhancing feature of Paligunj WUA and Bihar state PIM.

\subsubsection{R.P. Channel 3 (Right Parallel Channel 3) WUA-Water User Association}

R.P. Channel 3 is an eight $\mathrm{km}$ long distributary canal originating from the Patna Canal, which is the main canal of the Eastern Sone Canal System built in 1874 in British India. It is situated about 57 $\mathrm{km}$ south of Patna in the Patna District of Bihar and is on the Sone river south of the Ganges river. The canal and scheme were transferred under PIM to the WUA which was formed and registered in 2002. The transferred command area totals 1600 ha and covers 12 villages. The area is largely flat with fertile alluvial soils. The R P Channel 3 WUA is centered around Mahabalipur village which has a population of about 6800. About 20 percent of the households belong to scheduled (backward) castes, 40 percent to other backward caste (OBC) and 40 percent belong to other/higher castes. The literacy rate of the village is 68 percent. In land holding distribution, about 50 percent of the farmers have less than one hectare of land, 40 percent have 2 to 4 hectares and 10 percent have over 4 hectares. Agriculture is the major source of income and the livelihoods of most of the people are connected with farming. The major crops in the village are rice and wheat. Other crops are chickpea, corn, moong and black gram and vegetable crops are green peas and potatoes. In terms of agricultural machinery, about 20-25 tractors are present in the village and they are also rented out by the owners.

Hearing about the success of the Paliganj WUA, some farmers of the villages around R P Channel 3 visited the Paliganj WUA and arranged a meeting with the leaders. In the meeting, they came to know about the usefulness and various benefits of having a WUA and how to organize it. The farmers were inspired by the Paliganj WUA and went from village to village talking to the people about the WUA idea. This eventually led to the formation of an ad-hoc committee/informal WUA in 1999. The R P Channel-3 WUA central level committee (CLC) was formally created and registered in 2002, with 12 village level committees (VLCs), and 24 CLC executive members. The VLCs have elected executive committees (ECs) with elected President and Vice-President, as well as Secretary, Treasurer. Two VLC EC members represent the VLC on the CLC. The CLC also has an elected EC, President and Vice-President, as well as a Secretary, Assistant Secretaries, and Treasurer. After the new women reservation quota policy mandated by Bihar, women have been made members of the WUA executives. Currently the CLC and VLC ECs has a woman member each. This is a good example of supporting gender inclusion-through mandatory government policy. 
Water distribution planning is done through consultation between the CLC and VLCs. The CLC is responsible for the overall scheduling and monitoring of the water supply. The VLCs are responsible for scheduling and monitoring at the village level. No fixed timings are usually given for the release of water in the canals. A $24 \mathrm{~h}$ notice is given before the release of the water and it is usually released continuously for seven days and then stopped. Water charges are collected through collection agents who are VLC members and a 10\% commission is given to them. The CLC supervises the collection and deposits the money with the government. The CLC or VLC has no authority to stop water supply for non-payment of water charges. If major repairs are need, the CLC raises the issue with the government and interacts with the government to try and get it organized. The tail-end farmers often indicate great difficulty in getting water.

The WUA executive members have attended more than 20 training programs as well as field visits organized by institutions such as WALMI. In one such program, the Secretary of the WUA had visited Andhra Pradesh, and was highly impressed on seeing the work there. On returning, he wrote to the irrigation department about urgent repairs needed to the canal, but there was no response. When the work was not carried out for long, he conveyed the problem to the media. The media put out an article in the newspapers reporting this problem. This brought the government functionaries under pressure and soon the necessary orders and tender were passed and the repair work was carried out. As a result the water started flowing even to the tail end farmers. The R.P. Channel case shows how a good model example such as the Paligunj WUA can be used to inspire others to take up PIM. It also shows the benefits of exposure to other state PIMs, as well as the strong role that media communication can play in creating pressure for solving persistent problems and take PIM forward.

\subsubsection{Jetwalia WUA—Jetwalia Upviratni Krishak Samiti}

The Jetwalia Sub-Distributary is located in the Muzzafarpur district of Bihar state, north of the Ganges river in a highly flood prone part of the state. The source of the water for the system is the Gandak river. The scheme was transferred to the WUA in 2007 with a command area of 3760 ha covering 15 villages. The main village Bhailui Khan served by the Jetwalia Sub Distrubutary is about $100 \mathrm{~km}$ north of Patna in the Sahebganj block of Muzzafarpur district. It is a medium sized village with a population of about 1300. About 50 percent of the households belong to scheduled (backward) castes, 25 percent to other backward caste $(\mathrm{OBC})$ and 25 percent belong to other castes. In education status, the literacy rate is 67 percent. The area has black, alluvial, as well as saline soils and the land topography is largely flat. Most of the farms are very small. About 70 percent of the farmers have less than 1 hectares of land, 15 percent have 1 to 2 hectares, 10 percent 2 to 5 hectares, and 5 percent over 5 hectares of land. Agriculture is the major source of income and the main occupation is farming, followed by labor. After the sowing is over, due to lack of work, many young men migrate to the cities and other areas for work. The rest of the farming operation is done then by older people and women. The main crops are rice and wheat, and other crops are maize, chilly, carom seeds, coriander and cauliflower. About $90 \%$ of the households are also involved in animal husbandry, and many are engaged in fisheries. In agricultural machinery, a large number of power tillers and tractors are present in the village.

Irrigation is of great importance and under a new state Chief Minister in 2007, the state policies were changed in favor of PIM and the operating ownership of canals such as the Jetwalia Sub-Distributary could be handed over to WUAs. With such transfer, the maintenance of the canal became a responsibility of the WUA and small repairs were to be carried out by them. The WUAs could more quickly and carry out repairs and maintenance without the need to wait for government action. This saved a lot of time as well as water showing the usefulness of PIM.

A leading farmer of the village, Nawal Kishore Singh (the present WUA president), read about the PIM initiative of the government in the local newspaper. The article had news regarding a meeting to be held by the government where more information regarding PIM and forming of WUAs would be given. He was well aware that the irrigation system and water availability in the village had deteriorated sharply, and the article indicated that by forming a WUA the water situation could be substantially 
improved. Inspired by the article, he rode his bicycle $40 \mathrm{~km}$ to attend the meeting held in Saraiya. In the meeting, he was impressed by the talk of the Water and Land Management Institute (WALMI) officials, and decided to take up the formation of a WUA in the village. With help from WALMI, an event was organized in the village to which all the farmers were invited. At the event there were talks as well as a puppet show through which the benefits of PIM and WUAs were conveyed to the farmers. Following this, a village level committee could be formed with 10-11 members. The people of other villages were initially reluctant to join, but with the help from WALMI officials and Chief Engineer Uma Shankar, meetings were conducted in all the villages and the resistance was overcome.

The Jetwalia Sub-Distributary Committee was formed in 2007, with 12 central level committees (CLCs) under it. At the time of its registration 300 members were present. At present there are 15 registered CLCs and they are responsible for overall scheduling and distribution of the water. Under each CLC there are village level committees (VLCs) which manage water distribution and fee collection at the village level. The VLCs have executive committees of 10-12 members. CLCs have representative members from each VLC - typically the VLC President. The CLCs handle the issues of maintenances and repairs. If any major repairs are needed, the CLC raises the issue with the government and tries to get it organized. CLCs also undertake the collection of water charges and depositing the money with the government The CLC has an elected executive committees (EC) with President, Vice-President, Secretary, Assistant Secretaries, and Treasurer. The VLCs also have a similar structure with elected ECs, a President, and others. Under VLCs, working committees are sometimes formed for small repair works and maintenance of the canal. After the new woman representative directive of the government, every CLC/VLC executive committee has a woman member. Currently the Dy. President is a woman. The selection/election to the EC is usually by consensus. A CLC EC member cannot join another CLC EC.

Regarding water distribution, the timing for the release of the water is not fixed in advance. The President or Secretary makes a request to the irrigation department, and based on this water is released in the branch canal. Based on the water flow/quantity, the schedule of water release to the VLCs and farmers is decided in the CLC. If water does not reach the tail-reach farmers, the head-reach farmers are told to take less water. After the irrigation season, water fees are collected based on the usage of water and this is through collection agents (usually local VLC members) who get a $10 \%$ commission. Members who had contributed earlier through labor or other means have to pay less. As per the government guidelines, $30 \%$ of the amount collected is to be deposited with the government and 70\% kept by the WUA. The money is deposited in a designated account of a bank nearby and this is usually done before the end of the financial year. The details of receipts and expenditures are recorded in account books.

After the efforts made by the WUA formed in 2007, remodeling of the canal was taken-up by the government in 2009 to improve the water reach to tail-end farmers, and this was completed in 2012. Following this, some problems of cracks were seen in the canal, but this time the repairs were immediately taken up by the WUA. Labor was hired and the problem was solved in a few days. After a few years, water started leaking through cracks again, but the WUA had less funds. It then collected additional contribution from the members including labor contribution, and in a short time the repairs were done and the leakage was stopped.

In 2014-2015 the executive committees was renewed/changed and new office bearers were elected. With the formation of the WUA, the water wastage and leakage has reduced considerably, also reducing the salinity problem, and the need to pump groundwater, thereby stopping water table decline. Farmers were stealing water from the canal for fisheries, but this has been stopped by the WUA. Farmers no longer have to write applications for repairs to the government and wait for months or years. The WUA has the resources and can carry it out directly. This shows the great benefits of devolution through PIM. The Jetwalia example shows the major role inspired leadership and its hard effort can play in bridging the gap between the need, the government and the farmers to bring change. It also shows the importance of active involvement of government agencies and officers. It also shows the importance of 
giving a significant part of the collected fees to the WUAs, thereby making repairs, maintenance and management more effective.

Overall the case studies show that there is substantial variation in the working of PIM across WUAs. The Maloibari case in Assam shows the application of floating pump centers in flood prone areas for lift irrigation. It also shows the importance of education and farmer initiative in initiating PIM, and of the alignment of government support with the same initiative. This can materialize despite the top-down approach of PIM in Assam. However, the Sukhajani case shows a lack of farmer initiative created by the top-down approach of the government. Thus, despite a strong demand for water created by market forces and a fairly easy situation, no effective farmer effort materializes to fix and better manage the system since the solution is expected from the government. The Khairani case shows the advantages of having strong community leadership, and achieving high devolution and effectiveness of PIM through strict enforcement of compliance. It also shows the importance of community cultures such as of Bodos in bringing strong involvement to solve tough problems, and yet the need for government support, resources and technical inputs to achieve better performance.

The Paligunj case shows the substantial usefulness of bringing external experts/knowledgeable people for initiating change as shown by the USAID project and WALMI teams. It also shows the importance of training and of creating a strong example. The R P Channel case shows the benefits of exposure to good examples and guidance from them and also demonstrates the usefulness of involving the media to create pressure for solving problems. The Jetwalia case shows the advantages of having inspirational and hard-working leadership, the power of an example, and the importance of sharing the water fees collected with the WUAs to motivate and support timely repairs and maintenance. The various cases show that the effectiveness of PIM varies substantially, and is influenced by many factors such as the impact of good examples, involvement of experts, education/literacy, farmer initiative, inspirational leadership, alignment of government support with farmer initiatives, entrepreneurial culture of certain communities, strong enforcement of compliance, the use of media to create pressure, and the sharing of water fees collected with the WUAs for motivating PIM and timely repairs and maintenance.

\section{Study of Member Profile, Inclusion, Participation and Devolution in the WUAs}

Further to the case studies, a primary survey of a sample of PIM institutions and their farmer members/ beneficiaries was conducted in both Assam and Bihar. The survey covered among many different aspects, the structural features of member profile, inclusion, participation and devolution of decision-making in the WUAs. The survey was done in the year 2018 and the sampling sought a distribution of farmers across different farm sizes and ethnic groups. The data were collected through a structured questionnaire in face to face interviews by trained hired local people in the local language. It was typically collected from the head of the households who were almost all men. (A separate gender survey was conducted of women from a sub-sample of the same households. These were woman to woman and the findings are reported in a separate paper.) In Assam, the areas of three WUA-CLCs were sampled for study on lines described above. Of these one was a river-lift irrigation system (Maloibari) and two were on canal irrigation systems (Jamuna and Japadong). 19 villages and 25 WUA-VLCs were covered, see Table 2 below. From these, a total of 252 farmers sample were surveyed in Assam. (Note that Sukahjani WUA covered in the case studies was substituted by Jamana WUA in the survey) 
Table 2. Water User Associations (WUAs) studied in Assam.

\begin{tabular}{|c|c|c|c|c|c|}
\hline $\begin{array}{l}\text { Scheme/WUA } \\
\text { /Village }\end{array}$ & $\begin{array}{l}\text { System of } \\
\text { Irrigation }\end{array}$ & $\begin{array}{c}\text { Central Level } \\
\text { Committee (CLC) }\end{array}$ & $\begin{array}{l}\text { Village Level } \\
\text { Committee(VLC) }\end{array}$ & Villages & $\begin{array}{l}\text { Farmers } \\
\text { Sample }\end{array}$ \\
\hline Maloibari & River-Lift & $\begin{array}{l}\text { Kollongpuria } \\
\text { Krishak Sastal } \\
\text { Committee } \\
\text { (Maloibari) }\end{array}$ & 12 & 5 & 85 \\
\hline Jamana & Canal & $\begin{array}{c}\text { Jamuna CAD } \\
\text { Division (Jamuna) }\end{array}$ & 5 & 6 & 85 \\
\hline \multirow[t]{2}{*}{ Japadong } & Canal & $\begin{array}{c}\text { Jopadong Pagladia } \\
\text { No } 2 \text { Group Bund } \\
\text { Dong Committee } \\
\text { (Jopadong) }\end{array}$ & 8 & 8 & 82 \\
\hline & & Total & 25 & 19 & 252 \\
\hline
\end{tabular}

In Bihar similarly, the areas of three WUA-CLCs were sampled and covered in the study. These were Paligunj, RP Channel-3 and Jetwalia, covering 26 villages and 26 WUA-VLCs, see Table 3 below. A total of 258 farmers were covered.

Table 3. List of WUAs covered in Bihar

\begin{tabular}{cccccc}
\hline $\begin{array}{c}\text { Scheme/WUA } \\
\text { /Village }\end{array}$ & $\begin{array}{c}\text { System of } \\
\text { Irrigation }\end{array}$ & $\begin{array}{c}\text { Central Level } \\
\text { Committee (CLC) }\end{array}$ & $\begin{array}{c}\text { Village Level } \\
\text { Committee (VLC) }\end{array}$ & Villages & $\begin{array}{c}\text { Farmers } \\
\text { Sample }\end{array}$ \\
\hline Paligunj & Canal & $\begin{array}{c}\text { Paliganj Viratni } \\
\text { Krishak Samiti } \\
\text { (Paliganj) } \\
\text { R.P.Channel 3 }\end{array}$ & 13 & 13 & 84 \\
RP Channel 3 & Canal & $\begin{array}{c}\text { Jetwalia Upbhitarni } \\
\text { Krishik Samiti } \\
\text { Jetwalia) }\end{array}$ & 6 & 7 & 6 \\
\hline
\end{tabular}

The land holding size/farm size profile in the sample is given in Table 4 below. It indicates that the land holdings are generally very small with marginal farmers ( $<1$ hectare) constituting more than 50 percent in both states. Small farmers (1-2 hectares) are next with about 30 percent contribution, and medium farmers (2-10 hectares) at only 18 percent on the whole, with no large farmers $(>10$ hectares). The average owned land holding profile shows that the land holding size is very small at 1.22 hectares. There is some leasing giving an operated area of about 1.32 hectares per farm. This indicates the prevalence of very small land holdings.

Table 4. Farm size and average land holding profile.

\begin{tabular}{cccc}
\hline Farmer Size (hec.) & Percent & Land & Average (ha) \\
\hline Marginal $(<1)$ & $52.5 \%$ & Owned & 1.22 \\
Small $(1-2)$ & $29.8 \%$ & Leased-in & 0.17 \\
Medium $(2-10)$ & $17.6 \%$ & Leased-out & 0.06 \\
Large $(>10)$ & $0 \%$ & Total Operated & 1.32 \\
\hline
\end{tabular}

The Table 5 below gives the ethnic profile in available caste and tribe information. The table shows that 27.5 percent belong to schedule (backward) castes, 15.3 percent belong to schedule (backward) tribes, 23.3 belong to other backward castes and 33.3 percent belong to other castes. Thus a large percentage belong to backward castes and tribes. 
Table 5. Social group/ethnicity profile.

\begin{tabular}{cc}
\hline Social Group & Percent \\
\hline Schedule Castes & 27.5 \\
Schedule Tribes & 15.3 \\
Other Backward Castes & 23.7 \\
Other Castes & 33.5 \\
\hline Total & 100.0 \\
\hline
\end{tabular}

An important objective of WUAs is to make water management more inclusive- that is have inclusive membership across farm size, social groups, ages and location-not exclude any group. Table 6 below provides the findings on inclusion of various kinds of individuals and groups in the WUAs as reported by survey respondents. The findings show that small/marginal farmers are included substantially, as is considered desirable to give them a voice, whereas for large farmers, the percentage is low. Even the landless/tenants are included significantly in the WUAs, but the inclusion of women is very low. This is higher in Bihar given that it is mandated in the PIM directives which make it compulsory to have at least one women representative in the WUA executive. There is inclusion of both lower and upper caste members in the executive committees. On the inclusion of experienced/older people and the youth, there is a large gap. While the former are included, very few youth/young people are included in the WUA executives. There is high inclusion of both head and tail reach farmers - which is important to address the problems of tail reach farmers who frequently suffer in water availability. On the whole, the WUA membership appear to be quite inclusive in social, economic and location terms-except for low inclusion of women and youth.

Table 6. Inclusion and Membership in the WUA ${ }^{1}$.

\begin{tabular}{ccccc}
\hline \multirow{2}{*}{ Individuals/Groups } & \multicolumn{2}{c}{ Percentage Respondents Indicating that They Are Included } \\
\cline { 2 - 5 } & \multicolumn{2}{c}{ Village Level Committee } & \multicolumn{2}{c}{ Central Level Committee } \\
\hline & $\begin{array}{c}\text { Membership } \\
\text { (General Body) }\end{array}$ & $\begin{array}{c}\text { Executive } \\
\text { Committee }\end{array}$ & $\begin{array}{c}\text { Membership } \\
\text { (General Body) }\end{array}$ & $\begin{array}{c}\text { Executive } \\
\text { Committee }\end{array}$ \\
\hline Large farmers & 16.1 & 13.9 & 23.7 & 22.2 \\
Small/Marginal Farmers & 98.8 & 93.7 & 55.7 & 53.3 \\
Landless/Tenants & 76.9 & 45.9 & 40.4 & 37.1 \\
Women & 14.5 & 8.8 & 12.2 & 12.0 \\
People of dominant religions & 76.9 & 72.2 & 47.1 & 46.1 \\
People of minority religions & 36.3 & 30.8 & 30.8 & 24.5 \\
Upper castes/social groups & 71.0 & 61.6 & 55.7 & 53.3 \\
Lower castes/social groups & 95.1 & 90.6 & 59.2 & 57.6 \\
Experienced/older people & 95.9 & 81.0 & 58.0 & 54.5 \\
Youth (Between 15-30 years) & 62.0 & 33.9 & 25.3 & 15.5 \\
Panchayat officials & 26.7 & 15.5 & 19.0 & 16.9 \\
Government officials & 12.9 & 4.3 & 7.5 & 6.9 \\
Head reach farmers & 99.0 & 95.1 & 59.4 & 56.1 \\
Tail reach farmers & 98.6 & 92.5 & 57.3 & 55.1 \\
\hline
\end{tabular}

${ }^{1}$ : Responses captured as Yes and No. The figures reported are the \% of respondents saying yes.

Table 7 below shows the findings on whether there is active involvement of different kinds of people and bodies in the WUA. This means active involvement in the decision-making, which could be through roles in the leadership, executive or active engagement in the meetings. This is rated between 5 to 1,5 being strongly agree and 1 being strongly disagree, on their active involvement in the WUA. The results are provided in terms agree response percentage (strongly agree plus agree) on each question, as well as the mean of the response. The findings indicate that there is considerable variation 
in the reported involvement. It is found that the involvement of CLC members and officials is quite low and less than the involvement of VLC members and officials. Local institutions such as panchayat, cooperative societies, and banks are not actively involved in the WUAs. Government officials are also not actively involved. The involvement of women in WUA activities is very low. The involvement of low income people is greater than that of the high income people-which is positive from equity point of view. The involvement of landless, tenants and wage earners in the WUA is also quite high (through committees and general body meetings), which shows that there is active involvement in the WUAs irrespective of landholdings. Though people from both upper and lower caste are actively involved in WUA, the involvement of minority religion people is low. The involvement of lower caste people is higher than that of upper caste people-except in CLC. This indicates that there is apparently very little bias against the lower caste people esp. at VLC level. Head reach and tail reach farmers are both actively involved in WUA. Comparing involvement of youth versus older and experienced people, the involvement of youth is low.

Table 7. Involvement of different people and groups in the WUA.

\begin{tabular}{|c|c|c|}
\hline \multirow[t]{2}{*}{ Individuals/Groups } & \multicolumn{2}{|c|}{ They Are Actively Involved-Percent Response } \\
\hline & Agree $(\%)$ & Mean ${ }^{1}$ \\
\hline 1. CLC General Body & 33.9 & 2.5 \\
\hline 2. CLC Executive Committee & 32.3 & 2.4 \\
\hline 3. CLC President/Vice-President & 36.7 & 2.6 \\
\hline 4. CLC Secretary/Staff & 32.4 & 2.4 \\
\hline 5. VLC General Body & 52.3 & 3.0 \\
\hline 6. VLC Executive Committee & 53.1 & 3.2 \\
\hline 7. VLC President/Vice-President & 60.4 & 3.4 \\
\hline 8. VLC Secretary/Staff & 53.9 & 3.2 \\
\hline 9. WUA Members & 69.2 & 3.6 \\
\hline 10. WUA Non-members & 35.1 & 2.4 \\
\hline 11. Panchayat/Sarpanch & 11.4 & 1.5 \\
\hline 12. Cooperative Societies & 3.2 & 1.1 \\
\hline 13. Banks & 3.5 & 1.2 \\
\hline 14. Government Officials & 12.4 & 1.5 \\
\hline 15. Religious groups/institutions & 19 & 1.7 \\
\hline 16. Women & 5.3 & 1.2 \\
\hline 17. High Income & 62.9 & 3.3 \\
\hline 18. Low Income/Poor & 82.1 & 4.0 \\
\hline 19. Large/medium farmers & 78 & 3.8 \\
\hline 20. Small/marginal farmers & 82.4 & 4.0 \\
\hline 21. Landless/Tenants/Labor/Wage earners & 67.3 & 3.5 \\
\hline 22. People of dominant religions & 82 & 3.9 \\
\hline 23. People of minority religions & 21.8 & 1.8 \\
\hline 24. Upper Caste/social groups & 68.8 & 3.4 \\
\hline 25. Lower Caste/social groups & 84.9 & 4.1 \\
\hline 26. Head Reach Farmers & 90.8 & 4.2 \\
\hline 27. Tail Reach Farmers & 89 & 4.2 \\
\hline 28. Older/Experienced Farmers & 83.6 & 4.0 \\
\hline 39. Youth/Young Farmers (Between $15-29$ years) & 41 & 2.5 \\
\hline
\end{tabular}

${ }^{1}$ : Likert scale: Strongly agree (5), Agree (4), Partly agree/disagree (3), Disagree (2) Strongly disagree (1).

A major objective of PIM is the devolution of authority, responsibility and decision-making regarding water management down from the government to the WUAs and the farmers. Table 8 below provides findings on to what extent this is taking place with reference to different decisions/activities. The results show that largely it is the government which makes the decisions regarding planning for capital investment in irrigation structures, providing resources for investments, fixing the price of water 
paid to the government and collected from the farmers. These decisions show very little devolution. However, it is largely the CLC which decides on the assessment of water availability, scheduling of water release, actual release, as well as planning and undertaking repairs and maintenance. These decisions show some devolution. It is largely the VLC which decides on/undertakes distribution of water among the farmers, collection of fees, and monitoring use and misuse. These decisions/activities show considerable devolution. Finally, the decision on the crops to be grown remains almost completely devolved to the farmers.

Table 8. Devolution of Activities and Decision-Making.

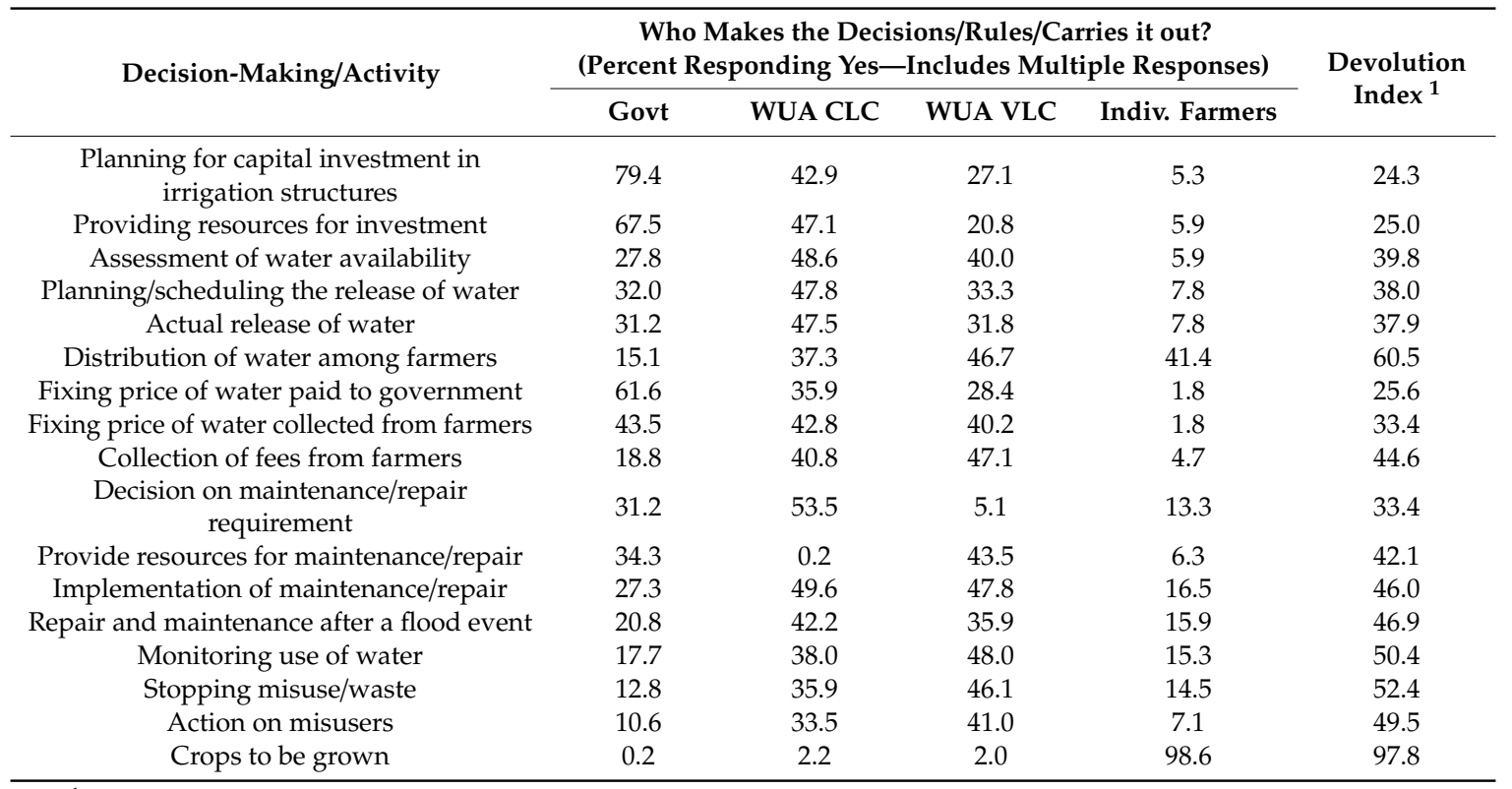

${ }^{1}$ : Devolution index scores: If Government $=0, \mathrm{CLC}=0.33, \mathrm{VLC}=0.67$, Farmer $=1.00$. Index $=$ Average weighted by percentages.

A devolution index is calculated to show the extent of devolution in different decisions and activities-using a method given in the Table notes. It indicates that there is low devolution in capital investment, in providing capital resource and in water pricing but high devolution in crops to be grown, monitoring use/misuse of water, carrying out repairs and maintenance, and collecting fees from the farmers. Thus, devolution envisaged in PIM has made progress but remains mixed across decisions/activities with scope for further improvement.

Table 9 examines the views on who decides the rules and systems of the WUA-whether it is the government or the farmers/members. Majority of the respondents disagree that the rules and systems are decided by the government (53 percent), and the majority agree that they are determined by farmers/WUA (64 percent). However, a majority indicate that they are jointly decided (54 percent). The findings indicate that there is considerable devolution towards joint decision-making and as well as WUAs/farmers deciding. 
Table 9. Who Decides the Rules and Systems of WUA (percent response).

\begin{tabular}{|c|c|c|c|c|c|c|}
\hline Who Decides the Rules and Systems & 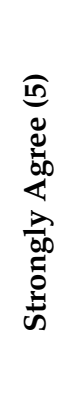 & 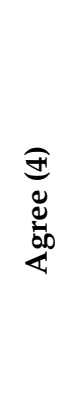 & 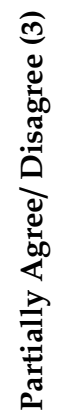 & 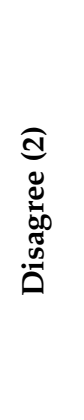 & 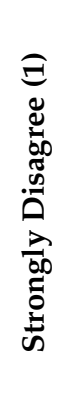 & $\sum_{\Sigma}^{\Xi}$ \\
\hline $\begin{array}{l}\text { The rules and systems are mainly } \\
\text { decided by the government }\end{array}$ & 6.5 & 31.4 & 9.2 & 35.3 & 17.6 & 2.74 \\
\hline $\begin{array}{l}\text { The rules and systems are mainly } \\
\text { decided by the farmers/WUA }\end{array}$ & 26.3 & 37.8 & 7.8 & 22.7 & 5.3 & 3.57 \\
\hline $\begin{array}{l}\text { The rules and systems are mainly } \\
\text { decided jointly }\end{array}$ & 14.3 & 39.4 & 5.5 & 35.9 & 4.9 & 3.22 \\
\hline
\end{tabular}

\section{Assessment of the Performance of the Water-User Associations}

To assess the performance of the WUAs, beneficiaries were asked questions regarding the performance on different dimensions including water availability, economic benefits, equity, environment, finance and overall performance. The summary of the responses obtained on a 5-point Likert scale of $5=$ excellent to $1=$ very poor are reported in Table 10.40 percent have rated the performance as good and only 6 percent have rated excellent. On the other hand, about 29 percent rate it as somewhat poor and 12 percent very poor. Views on other dimensions show considerable variation in the performance. Especially in water availability, equity and finance, many report poor performance.

Table 10. Assessment of the performance of WUAs.

\begin{tabular}{lcccccc}
\hline Performance Aspects & $\begin{array}{c}\text { Excellent } \\
\text { (5) }\end{array}$ & Good (4) & $\begin{array}{c}\text { Satisfactory } \\
\mathbf{( 3 )}\end{array}$ & $\begin{array}{c}\text { Somewhat } \\
\text { Poor (2) }\end{array}$ & $\begin{array}{c}\text { Very Poor } \\
\text { (1) }\end{array}$ & Mean \\
\hline $\begin{array}{l}\text { 1. Overall Assessment of the } \\
\text { Performance of the WUA }\end{array}$ & 5.88 & 39.41 & 13.73 & 28.63 & 12.35 & 2.98 \\
$\quad \begin{array}{l}\text { 2. Performance on Water } \\
\quad \text { Availability and Use }\end{array}$ & 2.16 & 29.61 & 27.84 & 29.41 & 10.98 & 2.83 \\
$\begin{array}{l}\text { 3. Performance on Economic } \\
\quad \text { Benefits }\end{array}$ & 0.39 & 30.20 & 45.10 & 17.25 & 7.06 & 3.00 \\
$\begin{array}{l}\text { 4. Performance on Equity in } \\
\text { Water Distribution and Benefits }\end{array}$ & 2.55 & 32.75 & 26.86 & 29.22 & 8.63 & 2.91 \\
$\quad \begin{array}{c}\text { 5. Performance on } \\
\text { Environment Care and Impact } \\
\text { 6. Performance on Financial } \\
\quad \text { Management }\end{array}$ & 0.78 & 39.22 & 33.14 & 20.59 & 6.27 & 3.08 \\
\hline
\end{tabular}

\section{Regression Analysis: Relationship of Performance to Involvement and Devolution}

To explore the possible relationship of performance with participation/involvement and devolution in a multivariate framework, regression analysis is used [33]. A composite of the six different performance indicator responses (range from 5: Excellent to 1: very poor) and is used to represent performance. Participation/involvement and devolution are measured as shown in the respective tables above through member responses. A state dummy is also included given that the data is from two different states (Assam and Bihar). Ordered Probit is considered the appropriate econometric technique of analysis [34] given the nature of the performance indicator. The latent model is stated as:

$$
y^{*}=x^{\prime} \beta+\varepsilon
$$




$$
\begin{gathered}
y=0 \text { if } y^{*} \leq 0 \\
=1 \text { if } 0<y^{*} \leq \mu_{1} \\
=2 \text { if } \mu_{1}<y^{*} \leq \mu_{2} \\
=3 \text { if } \mu_{2}<y^{*} \leq \mu_{3} \\
=4 \text { if } \mu_{3}<y^{*} \leq \mu_{4} \\
=5 \text { if } y^{*}>\mu_{4}
\end{gathered}
$$

The results of the Ordered Probit Regression between performance and the reported active involvement of different officials and kinds of people are given in the Table 11 below. The results indicate that the active involvement of the Central Level Committee (CLC) President/Vice-President is very important and is positively and significantly related to performance. In the cases, this is demonstrated by the Jetwalia and Paligunj WUAs. The active involvement of ordinary members is also positively and significantly related to performance indicating the importance of ordinary member participation and involvement. The involvement of Village Level Committee (VLC) President/Vice-President is not strongly related to performance and that of non-members has a somewhat negative relationship but is not very significant. Active involvement of upper caste social group however shows a negative (and significant) relationship with performance. Active involvement of tail reach farmers, older experienced farmers, and youth/young farmers all have a positive and significant associations with performance. Findings indicate the active involvement/participation of the CLC President/Vice-President, and also of several other groups/bodies including tail reach farmers, older/experienced people, and the youth mentioned above, is of substantial importance for good performance.

Table 11. Ordered Probit Regression Results_Performance and Involvement.

\begin{tabular}{cccccc}
\hline Variables: Active Involvement of: & DF & $\begin{array}{c}\text { Coefficient } \\
\text { Estimate }\end{array}$ & $\begin{array}{c}\text { Standard } \\
\text { Error }\end{array}$ & $t$ Value & Approx Pr $>|\mathbf{t}|$ \\
\hline Intercept & 1 & -1.765690 & 0.332041 & -5.32 & $<0.0001$ \\
CLC_President_Vice_President & 1 & 0.270512 & 0.041117 & 6.58 & $<0.0001$ \\
VLC_President_Vice_President & 1 & -0.010640 & 0.048352 & -0.22 & 0.8258 \\
WUA_Members & 1 & 0.177972 & 0.055223 & 3.22 & 0.0013 \\
WUA_Non_members & 1 & -0.071805 & 0.045174 & -1.59 & 0.1119 \\
Panchayat_Sarpanch & 1 & 0.071806 & 0.055718 & 1.29 & 0.1975 \\
Cooperative_Societies & 1 & 0.129011 & 0.097826 & 1.32 & 0.1872 \\
Government_Officials & 1 & -0.018956 & 0.060927 & -0.31 & 0.7557 \\
Women & 1 & 0.011171 & 0.073572 & 0.15 & 0.8793 \\
Large_medium_farmers & 1 & 0.055275 & 0.052919 & 1.04 & 0.2962 \\
Small_marginal_farmers & 1 & 0.023873 & 0.066815 & 0.36 & 0.7209 \\
Upper_Caste_social_groups & 1 & -0.108657 & 0.046347 & -2.34 & 0.0191 \\
Lower_Caste_social_groups & 1 & -0.000742 & 0.066256 & -0.01 & 0.9911 \\
Head_Reach_Farmers & 1 & -0.001075 & 0.082460 & -0.01 & 0.9896 \\
Tail_Reach_Farmers & 1 & 0.165539 & 0.080878 & 2.05 & 0.0407 \\
Older_Experienced_Farmers & 1 & 0.219971 & 0.069355 & 3.17 & 0.0015 \\
Youth_Young_Farmers & 1 & 0.181706 & 0.053551 & 3.39 & 0.0007 \\
State_Dummy_Assam & 1 & 0.316193 & 0.218553 & 1.45 & 0.1480 \\
\hline
\end{tabular}

Pseudo $R^{2}$ : Estrella $=0.468$, Veall-Zimmermann $=0.4921$.

The relationship of performance with devolution was also explored. The results of the Ordered Probit Regression between performance and devolution are given in Table 12 below. Devolution is calculated as an index as described above-greater the devolution, higher the index. The Table 10 below relates the performance to the overall devolution index, which is calculated as a composite of the devolution indices of each of the decisions/activities. The regression results indicate a highly significant positive association between performance and devolution. This shows that greater the overall devolution, better the performance. 
Table 12. Ordered Probit Regression Results-Performance and Overall Devolution.

\begin{tabular}{cccccc}
\hline Variable & DF & Estimate & Standard Error & $\boldsymbol{t}$ Value & Approx Pr $>|\mathbf{t}|$ \\
\hline Intercept & 1 & -0.745417 & 0.154624 & -4.82 & $<0.0001$ \\
Devolution_Index & 1 & 0.048121 & 0.003466 & 13.88 & $<0.0001$ \\
State_Dummy_Assam & 1 & 0.719403 & 0.103060 & 6.98 & $<0.0001$ \\
\hline
\end{tabular}

Pseudo $R^{2}$ : Estrella $=0.4144$, Veall-Zimmermann $=0.4465$.

Further, the relationship of performance with devolution on each of the decisions/activities covered is explored. The results of the Ordered Probit Regression between performance and the devolution indices of each of the covered decisions/activities are given in Table 13 below. The results show that devolution of planning (planning for capital investment in irrigation structures) has a strongly positive and significant association with performance. However, devolution of investment (providing resources for investment) has a negative and significant association. This is demonstrated in the cases discussed including Khairani WUA which finds its resources insufficient and obtains government assistance through which durable and technically sound structures are built which are far more effective. This is also demonstrated by the Jetwalia and R.P. Channel-3 WUAs which approach the government for major repairs of the canal, thereby substantially improving performance. Other analysis shows that the negative effect of devolution of investment has more impact on environment, equity and economic benefits. Devolution of water release (actual release of water) decisions has a positive association with performance which is significant (though not highly). This is shown by the Maloibari WUA. The devolution of farmer water price fixing decision (fixing price of water collected from farmers) also has a strong positive and significant association with performance indicating the usefulness of its devolution. The devolution of water fee collection (collection of fees from farmers) has a strong positive and significant association with performance indicating the usefulness of devolving this. This is shown by both the Paligunj and Jetwalia WUAs. The devolution of repair and maintenance implementation (implementation of maintenance/repair) also has a positive association but this is not statistically significant. The results indicate that there is variation but the devolution of a number of decisions/activities of has a strong positive association with performance, whereas devolution of a few shows a negative impact.

Table 13. Ordered Probit Regression Results—Performance and Devolution.

\begin{tabular}{cccccc}
\hline Variables: Index of Devolution & DF & $\begin{array}{c}\text { Coefficient } \\
\text { Estimate }\end{array}$ & $\begin{array}{c}\text { Standard } \\
\text { Error }\end{array}$ & $\boldsymbol{t}$ Value & Approx Pr $>|\mathbf{t}|$ \\
\hline Intercept & 1 & -0.212069 & 0.869018 & -0.24 & 0.8072 \\
Planning_Index & 1 & 0.014786 & 0.004603 & 3.21 & 0.0013 \\
Investment-Reso_Index & 1 & -0.008950 & 0.004500 & -1.99 & 0.0467 \\
Waterassess_Index & 1 & 0.003035 & 0.004698 & 0.65 & 0.5183 \\
Waterreleaseplan_Index & 1 & 0.007163 & 0.004459 & 1.61 & 0.1082 \\
Actualrelease_Index & 1 & 0.000314 & 0.004430 & 0.07 & 0.9434 \\
Distrubution_Index & 1 & 0.001283 & 0.003440 & 0.37 & 0.7092 \\
Fixingpricegov_Index & 1 & -0.000451 & 0.004678 & -0.10 & 0.9232 \\
Fixingpricefarmers_index & 1 & 0.016781 & 0.004661 & 3.60 & 0.0003 \\
Collectionfees_Index & 1 & 0.020184 & 0.005634 & 3.58 & 0.0003 \\
Maintenance-dec_Index & 1 & -0.002229 & 0.003795 & -0.59 & 0.5569 \\
Maint-resources_Index & 1 & -0.000711 & 0.004869 & -0.15 & 0.8838 \\
Maint-implement_Index & 1 & 0.006965 & 0.005015 & 1.39 & 0.1649 \\
Repairflood_Index & 1 & -0.003257 & 0.003422 & -0.95 & 0.3412 \\
Monitor_Index & 1 & -0.000105 & 0.004617 & -0.02 & 0.9818 \\
Misuse-stop_Index & 1 & -0.000465 & 0.004473 & -0.10 & 0.9172 \\
Misuser-act_Index & 1 & -0.002002 & 0.004652 & -0.43 & 0.6670 \\
Cropsgrown_Index & 1 & 0.002218 & 0.008515 & 0.26 & 0.7945 \\
State_Dummy_Assam & 1 & 0.695851 & 0.193172 & 3.60 & 0.0003 \\
\hline
\end{tabular}

Pseudo $\mathrm{R}^{2}$ : Estrella $=0.5866$, Veall-Zimmermann $=0.5935$. 


\section{Conclusions}

Water institutions are crucial for better water resource management in eastern India and though there are examples of spontaneous bottom-up initiatives, much of the development is driven by government interventions including laws, policies, and government programs. Despite this, WUAs show substantial variation. The literature indicates that PIM is found to be beneficial on a number of counts and across many locations in the world. It is widely accepted that PIM generally contributes to better water management, greater accountability, reduced government cost, and improved sustainability of operations. In Assam and Bihar, considerable progress has been made in building an institutional framework for PIM, though much further improvement is required. Both states have passed special Acts to enable PIM, but implementation and spread of PIM remains slow. However, the case studies show that there are good example in both states where PIM has been successfully implemented and a significant impact is created. The PIM institutions in both Assam and Bihar are found to be quite inclusive of farmers from both lower and upper social and economic groups, with the exception of poor inclusion of women and youth. The active involvement of different officials and groups however shows considerable variation, and this is better at the VLC level. Results on devolution indicate considerable progress, but capital investment and water pricing decisions remain quite centralized. More devolution is seen in water distribution, monitoring use/misuse of water, collection of fees, and managing repairs and maintenance. Most respondents indicate that the rules and systems of water management are determined by the farmers or jointly with the government, indicating that devolution and empowerment are taking place in participatory irrigation management.

The case studies show that there is substantial variation in the working of PIM across WUAs. The Maloibari case in Assam shows the importance of education, farmers initiative, and government support aligned with the same initiative. It shows the benefits of devolution and decentralization of decision-making. The Sukhajani case shows that a lack of farmer initiative is created by the top-down approach of the government. It also shows that a change from a top-down to a bottom-up approach helps PIM significantly. The Khairani case shows the advantages of strong farmer and community leadership, and achieving high effectiveness of PIM through strict enforcement of compliance. It is also an excellent example and proof of a completely decentralized decision-making and farmer managed system. It also shows, as indicated by Phadke [10], that resilient PIM institutions are best built from ground up. The Paligunj case shows the usefulness of external expert inputs in the initiation of PIM and the impact of creating a good example. This is in line with Abu-Zeid and Assioutti [22] who indicate that capacity building is a must for WUAs and helps to improve their adaptiveness and flexibility. It also demonstrates the substantial benefits of devolution through PIM. The R P Channel case demonstrates the usefulness of media in creating pressure for change. It also shows the positive effective of mandatory gender inclusion-coming from government policy. The Jetwalia case shows the advantages of having inspirational and hard-working leadership, the power of an example, and the importance of financial devolution-sharing government funds with the WUAs to motivate PIM and support timely maintenance.

The findings through regression analysis show that active involvement of the CLC President and of WUA members is strongly and positively associated with better performance. The active involvement of tail reach farmers, older farmers and youth is also positively and significantly related to better performance. However, active involvement of upper caste social groups is negatively related. On devolution, the results show that greater overall devolution of decision-making/activities is strongly and positively associate with better performance. Among the different decisions/activities, devolution of planning has a positive and significant association with performance. However, devolution of investment has a negative and significant association. This relationship is shown by a number of WUAs including Khairani and Jetwalia. Devolution of water release decisions, farmer price-fixing, water fee collection, and of repair and maintenance activities all show positive associations with performance. Thus, devolution in general, and devolution particularly of planning, water release, farmer price-fixing, 
water fee collection, and repair and maintenance, are positively associated, and could significantly enhance performance in water resource management.

Author Contributions: V.P.G.—conceptualization, research design, writing; N.J.- field research, data analysis, writing; K.N.-literature review; D.J.--field research. All authors have read and agreed to the published version of the manuscript.

Funding: This research was funded by the Australian Centre for International Agricultural Research (ACIAR) project ADP2014/045.

Acknowledgments: The authors would like to thank numerous researchers for their inputs, ACIAR for their support, state governments for their assistance, respondents for their time, and numerous workshop participants for their helpful comments.

Conflicts of Interest: The authors declare no conflict of interest.

\section{References}

1. Kulkarni, S.A.; Tyagi, A.C. Participatory Irrigation Management: Understanding the Role of Cooperative Culture; International Commission on Irrigation and Drainage: New Delhi, India, 2012; Available online: https: //www.un.org/waterforlifedecade/water_cooperation_2013/pdf/ICID_Paper_Avinahs_Tyagi.pdf (accessed on 25 June 2019).

2. Shah, T. Past, Present, and the Future of Canal Irrigation in India. In Water: Policy and Performance for Sustainable Development; India infrastructure report; Infrastructure Development Finance Company, Ed.; Oxford University Press: New Delhi, India, 2011; pp. 69-89. ISBN 978-0-19-807885-2.

3. Hunt, R. Appropriate Social Organization? Water User Associations in Bureaucratic Canal Irrigation Systems. Hum. Organ. 1989, 48, 79-90. [CrossRef]

4. Narain, V. Crafting Institutions for Collective Action in Canal Irrigation: Can We Break the Deadlocks? In Governance of Water. Institutional Alternatives and Political Economy; Ballabh, V., Ed.; Sage: New Delhi, India, 2008; pp. 159-173.

5. Subramanian, A.; Jagannathan, N.V.; Meinzen-Dick, R.S. User Organizations for Sustainable Water Services; World Bank Technical Paper; World Bank Publications: Washington, DC, USA, 1997; ISBN 978-0-8213-3855-1.

6. Vaidyanathan, A. Water Resource Management: Institutions and Irrigation Development in India; Oxford University Press: Oxford, UK, 1999; ISBN 978-0-19-564631-3.

7. Gandhi, V.P.; Namboodiri, N.V. Participatory Irrigation Management-An Evaluation of the Performance in Andhra Pradesh, Gujarat and Maharastra; Centre for Management in Agriculture, IIMA: Ahmedabad, India, 2009; Available online: https://www.iima.ac.in/c/document_library/get_file?uuid=a5eced82-3f75-4068-9aa157aef9de0876\&groupId $=62390$ (accessed on 20 June 2019).

8. Aarnoudse, E.; Closas, A.; Lefore, N. Water user associations: A Review of Approaches and Alternative Management Options for Sub-Saharan Africa; International Water Management Institute (IWMI): Colombo, Sri Lanka, 2018.

9. Swain, M.; Das, D.K. Participatory irrigation management in India: Implementations and gaps. J. Dev. Sustain. Agric. 2008, 3, 28-39.

10. Phadke, R. Water Works in India. J. Political Ecol. 2013, 20, 80-97. [CrossRef]

11. Coward, E. Property Rights and Network Order: The Case of Irrigation Works in the Western Himalayas. Human Organ. 1990, 49, 78-88. [CrossRef]

12. Meinzen-Dick, R.; Raju, K.V.; Gulati, A. What Affects Organization and Collective Action for Managing Resources? Evidence from Canal Irrigation Systems in India. World Dev. 2002, 30, 649-666. [CrossRef]

13. Meinzen-Dick, R. Beyond panaceas in water institutions. Proc. Natl. Acad. Sci. USA 2007, 104, 15200-15205. [CrossRef] [PubMed]

14. Vermillion, D.L.; Sagardoy, J.A. Transfer of Irrigation Management Services: Guidelines; FAO Irrigation and Drainage Paper; Food and Agriculture Organization of the United Nations (FAO): Rome, Italy, 1999; ISBN 978-92-5-104308-0.

15. Vermillion, D.L. Impacts of Irrigation Management Transfer: A Review of the Evidence; International Water Management Institute: Colombo, Sri Lanka, 1997; Available online: https://ageconsearch.umn.edu/record/ 52798 (accessed on 25 September 2019).

16. Senanayake, N.; Mukherji, A.; Giordano, M. Re-visiting what we know about Irrigation Management Transfer: A review of the evidence. Agric. Water Manag. 2015, 149, 175-186. [CrossRef] 
17. Lam, W.F. Governing Irrigation Systems in Nepal: Institutions, Infrastructure, and Collective Action; Institute for Contemporary Studies: San Francisco, CA, USA, 1998.

18. Araral, E. The Impact of Decentralization on Large Scale Irrigation: Evidence from the Philippines. Water Altern. 2011, 4, 110-123.

19. Zhou, Q. Decentralized irrigation in China: An institutional analysis. Policy Soc. 2013, 32, 77-88. [CrossRef]

20. Mollinga, P.P.; Meinzen-Dick, R.S.; Merrey, D.J. Politics, Plurality and Problemsheds: A Strategic Approach for Reform of Agricultural Water Resources Management. Dev. Policy Rev. 2007, 25, 699-719. [CrossRef]

21. Garces-Restrepo, C.; Vermillion, D.L.; Muñoz, G. Irrigation Management Transfer: Worldwide Efforts and Results; Food and Agriculture Organization of the United Nations: Rome, Italy, 2007; ISBN 978-92-5-105907-4.

22. Abu Zeid, M.; El-Assiouti, I. Capacity building, a precondition for sustainable participatory irrigation management in Egypt. Medit 1997, 8, 18-22.

23. Government of Assam. The Assam Irrigation Water Users Act 2004. Available online: https://irrigation. assam.gov.in/sites/default/files/swf_utility_folder/departments/irrigation_webcomindia_org_oid_3/menu/ document/The \%20Assam\%20Irrigation\%20Water\%20Users\%20Act\%2C\%202004.compressed.pdf (accessed on 20 June 2019).

24. Government of Bihar. The Bihar Irrigation, Flood Management and Drainage Rules 2003. Available online: http://wrd.bih.nic.in/acts_rules/irrigation_rules_2003.pdf (accessed on 25 June 2019).

25. Ministry of Water Resources. Status of Participatory Irrigation Management (PIM) in India-Policy Initiatives Taken and Emerging Issues; Ministry of Water Resources: New Delhi. Available online: http://mowr.gov.in/ sites/default/files/CADWM_Status_of_PIM_0.pdf (accessed on 20 September 2019).

26. Jayashankar, V. Participatory Irrigation Management (PIM)-Bihar Model. Indian J. Public Adm. 2003, 49, 449-457. [CrossRef]

27. Asian Development Bank. Irrigation Management Transfer: Strategies and Best Practices; Asian Development Bank: Hong Kong, China, 2007; ISBN 978-93-5280-339-2.

28. Salman, S.M.A. The Legal Framework for Water Users' Associations: A Comparative Study; The World Bank: Washington, DC, USA, 1997; pp. 1-116.

29. Ministry of Water Resources. National Water Policy. 1987. Available online: http://jalshakti-dowr.gov.in/ sites/default/files/National\%20Water\%20Policy\%201987\%20English.pdf (accessed on 20 September 2019).

30. Government of Bihar. Bihar State Water Policy 1993; Government of Bihar: Patna, India, 1993.

31. Government of Bihar. Bihar Irrigation Act. 1997. Available online: http://www.ielrc.org/content/e9703.pdf (accessed on 10 July 2019).

32. Raju, K. Participatory Irrigation Management in Bihar: Status and Issues; Center for Ecological Economics and Natural Resources: Bangalore, India, 2006.

33. Gandhi, V.P.; Johnson, N. Enhancing Performance of Participatory Water Institutions in the Eastern Indo-Gangetic Plains: What Can We Learn from New Institutional Economics and Governance Theories? Water 2019, 12, 70. [CrossRef]

34. Greene, W.H. Econometric Analysis; Pearson Education India: Delhi, India, 2003; ISBN 978-81-7758-684-8.

(C) 2020 by the authors. Licensee MDPI, Basel, Switzerland. This article is an open access article distributed under the terms and conditions of the Creative Commons Attribution (CC BY) license (http://creativecommons.org/licenses/by/4.0/). 